\title{
EFFECTS OF SHRIMP TRAWLING ON THE STRUCTURE OF MACROBENTHIC COMMUNITIES OF PARANÁ'S INNER SHELF
}

\author{
PELAES, M.A.L. \& BORZONE, C.A. \\ Laboratório de Ecologia de Praias - CEM/UFPR \\ Av. Beira-mar s/n Caixa Postal/P.O.Box 50.002 \\ CEP: 83255-000 - Pontal do Sul Pontal do Paraná - PR - BRASIL \\ marcospelaes@yahoo.com.br; capborza@ufpr.br
}

\begin{abstract}
Pelaes, M.A.L. \& Borzone, C.A. 2007. Effects of shrimp trawling on the structure of macrobenthic communities of Paraná's inner shelf. Braz. J. Aquat. Sci. Technol. 11(2):45-51. ISSN 1808-7035. The objective of present contribution was analyzes disturbances caused by shrimp trawling on macrobenthic communities of soft bottom on two areas: one located within a currently trawled area and the other impacted in the past by trawling activity, but where supposingdly there is no trawling in the present. Samples were taken using an iron core of $0.05 \mathrm{~m}^{2}$ with a $500 \mu \mathrm{m}$ mesh attached to one of the core ends received the collected material by SCUBA diving. Bi-factorial analysis of variance (MANOVA) was performed to compare ecological descriptors for both areas. To analyze and compare the communities' structure was performed a MDS and similarity analyses (ANOSIM). It is not found significant difference for anything ecological descriptor, nor to the total of polychaetes, bivalves and crustaceans between areas. However, significant differences were found among months, except to the total of bivalves and Shannon \& Wiener diversity index, indicating that differences were more related to temporal variation than to area variation.
\end{abstract}

Key Words: macrobenthos, disturbance, fishing, biodiversity

\section{INTRODUCTION}

Fisheries are one of the most important human activity in any coastal zone, creating multiple interactions and reinforcing the need for an integrated approach towards coastal zone management. However, fishing methods differ markedly from region to region (Blaber et al., 2000).

There is now good evidence that commercial fishing has profound effects on marine ecosystems (Trush \& Dayton, 2002). Bottom trawl nets have been considered one of gears that cause the most serious disturbances on benthic communities (Kaiser, 2003).

The type of physical impact that fishing gear has on the sea floor depends on its mass, degree of contact with the sea floor, and the speed at which it is dragged. The way the gear is designed and operated also influences how it interacts with the seafloor and how many species other than the target species the gear removes from the seafloor or damages in situ (Thrush \& Dayton, 2002). These fishing gears are designed to penetrate the surface layers of the sediment, in order to increase catching of the target species (Ramsay et al, 1998).

Trawling also increases the abundance of fastgrowing species such as polychaetes at the expense of slower-growing, later-reproducing species such as mollusks and crustaceans (Engel \& Kvitek, 1998).
Some studies show that areas affected by bottom trawling favor certain predator species by exposition or damage to burried animals. These injured or dead animals not caught by trawling, might be turned into an important food resource for scavenger species (Ramsay et al., 1998).

According to Engel \& Kvitek (1998), intense trawling significantly reduces the heterogeneity of bottom habitats. Thus, the possibilities of adaptative success of organisms are reduced, therefore increasing the potential environmental biodiversity.

Even though negative trawling effects on marine ecosystems are not totally confirmed, some management policies aim to reduce trawling areas. (Trush et al, 2001). In the Paraná coast, a system of anti-trawling devices has recently been placed, creating an area of trawling exclusion to protect the sea bottom and traditional fishing (Brandini, 2003).

The coast of the state of Paraná is $90 \mathrm{~km}$ long. The straight sandy shore is interrupted by Guaratuba bay (at the southern) and Paranaguá bay (northern) outlets (Noernberg, 2001). The inner shelf is constituted predominantly by fine sand, with lens of medium sand between $10 \mathrm{~m}$ and $15 \mathrm{~m}$ depth (Veiga et al., 2004). It represents a suitable area for commercial shrimp trawling, and vessels from other states explore these extensive fishing grounds since 1971 (Perez \& Pezzuto, 1998). An anti-trawling devices were placed in 2000 and 
consist of a trail of iron drums filled with concrete. Each drum has two perpendicular train rails on its top. These devices form an "anti trawling system", located at approximately three nautical miles from the coast and delimited proximal areas with and without trawling operation.

Although many trawl-impact studies have been performed along continental shelves around the world, our study is one of the first of the Paraná's coast in southern Brazil.

\section{MATERIAL AND METHODS}

The present contribution analyzes disturbances caused by shrimp trawling on macrobenthic communities. Our study was performed on two areas: one located within a currently trawled area (at $12 \mathrm{~m}$ depth), about three nautical miles off the coast, outside the anti trawling system, and the other impacted in the past by trawling activity, but where supposingdly there is no trawling in the present (at $14 \mathrm{~m}$ depth), due to the installation of the anti-trawling devices (Fig. 1). Both areas have similar substratum composition and depth.

Samples were taken before (March 8), during (April 29) and after (June 10) the shrimp fishing closure from March $1^{\text {st }}$ to May $31^{\text {st }}, 2005$. At each of the two areas, named "impacted" and "control" (with and without trawling, respectively), properly positioned with a GPS, four sediment samples were collected in each area with an iron core of $0.05 \mathrm{~m}^{2}$ by SCUBA diving for analysis of macrobenthic communities. A 500 $\mu \mathrm{m}$ mesh attached to one of the core ends received the collected material

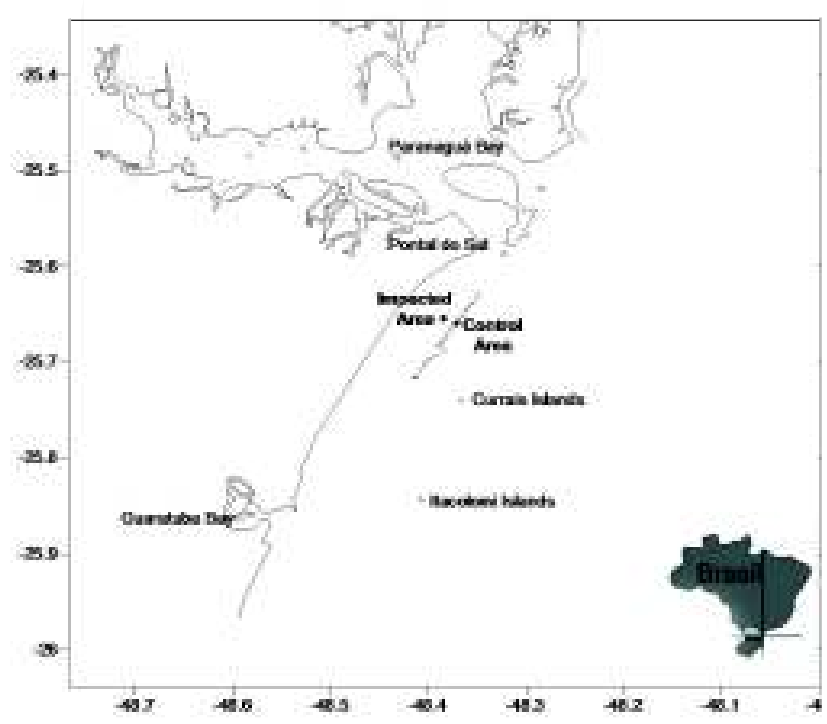

Figure 1 - Location of the control area and the impacted area and the anti-trawling structures placed in the Paraná coast in southern Brazil. (sediment and organisms) with a volume of $2,300 \mathrm{~cm}^{3}$. Samples were fixed in $10 \%$ formalin and organisms were sorted and identified to the lowest taxonomic possible level. Colonial organisms such as hydrozoa were counted as number of fragments.

Ecological descriptors as well as communities composition were compared for both areas. Bi-factorial analysis of variance (MANOVA) of total number of individuals and species (individuals or species number/ $2300 \mathrm{~cm}^{3}$ ), total of polychaetes, total of bivalves, total of crustaceans, Shannon \& Wiener $\left(\log _{2}\right)$ diversity index and Margalef's index of species richness were performed considering areas (with and without trawling) and period (before, during and after the fishing closure) as factors. To analyze and compare the communities' structure a MDS analysis was performed using a Bray-Curtis similarity index applied over a sample/species matrix square root transformed. A similarity analyses (ANOSIM) was performed using the same factors (area and period).

\section{RESULTS}

In the control area, polychaetes represented $50 \%$ of all individuals collected in March, followed by hydrozoa $(22 \%)$, bivalves and crustaceans ( $8 \%)$. At the impacted area, polychaetes represented $35 \%$, hydrozoa $38 \%$, crustaceans $15 \%$, and bivalves $5 \%$. An increase in the number of collected polychaetes was observed in April in both areas. In June, the control area presented $27 \%$ bivalves, followed by polychaetes (25\%), crustaceans (22\%) and the echinoid, Lytechinus variegatus (17\%). In the impacted area, polychaetes were dominant $(37 \%)$, followed by crustaceans $(30 \%)$ and bivalves $(15 \%)$; L.variegatus represented only $1 \%$ of the total.

The total number of individuals was not significantly different between areas. The interaction between area and month was not significant for the total number of individuals; it was significantly different among months (Table 1), with larger values for March (Fig. 2).

For number of species the pattern was repeated, with no significant differences between areas nor any interaction $\mathrm{A} / \mathrm{M}$, but reporting significant differences within months, with the least amount of species in April (Table 1, Fig. 3). The same results were observed for

Table 1 - Results of the MANOVA bifactorial for the total number of individuals, total number of species, total of polychaetes, total of bivalves and total of crustaceans.

\begin{tabular}{ccccccccccc}
\hline & \multicolumn{2}{c}{$\begin{array}{c}\text { Total number of } \\
\text { individuals }\end{array}$} & \multicolumn{2}{c}{ Total number of } & \multicolumn{2}{c}{ Total of } & \multicolumn{2}{c}{ Total of } & \multicolumn{2}{c}{ Total of } \\
& species & \multicolumn{2}{c}{$\begin{array}{c}\text { Polychaetes } \\
\text { Bivalves }\end{array}$} & \multicolumn{2}{c}{ Crustaceans } \\
& $\mathrm{F}$ & $\mathrm{p}$ & $\mathrm{F}$ & $\mathrm{p}$ & $\mathrm{F}$ & $\mathrm{p}$ & $\mathrm{F}$ & $\mathrm{p}$ & $\mathrm{F}$ & $\mathrm{p}$ \\
\hline Áreas & 0.135 & 0.718 & 0.603 & 0.448 & 0.074 & 0.788 & 1.072 & 0.314 & 0.755 & 0.396 \\
Months & 13.663 & 0.0002 & 6.681 & 0.007 & 8.35 & 0.003 & 2.016 & 0.162 & 7.22 & 0.005 \\
A/M & 1.417 & 0.268 & 2.422 & 0.117 & 2.153 & 0.145 & 1.446 & 0.262 & 0.447 & 0.646 \\
\hline \hline
\end{tabular}




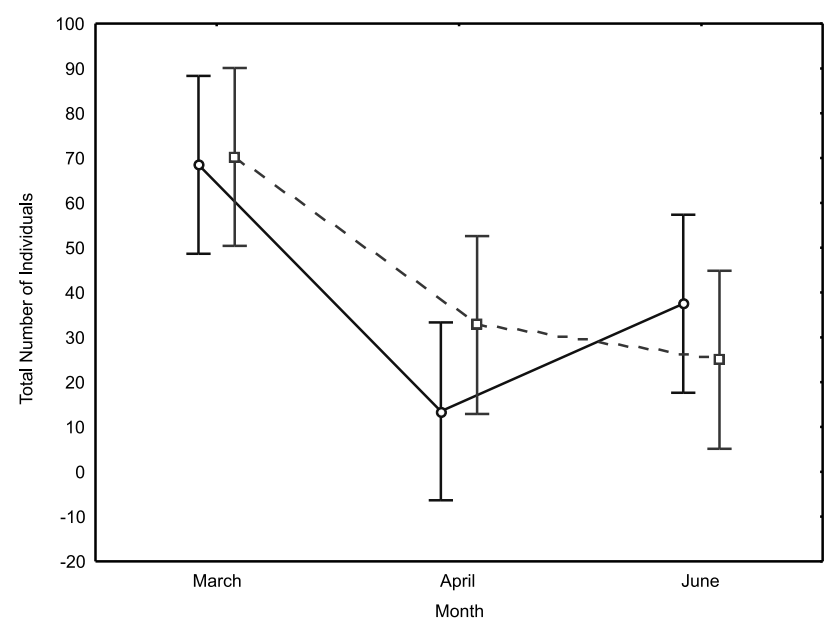

Figure 2 - Average (+/-Standard Deviation) of total number of indivíduals $/ 2300 \mathrm{~cm}^{3}$ for the three months. Control area: continuous line; impacted area: dashed line.

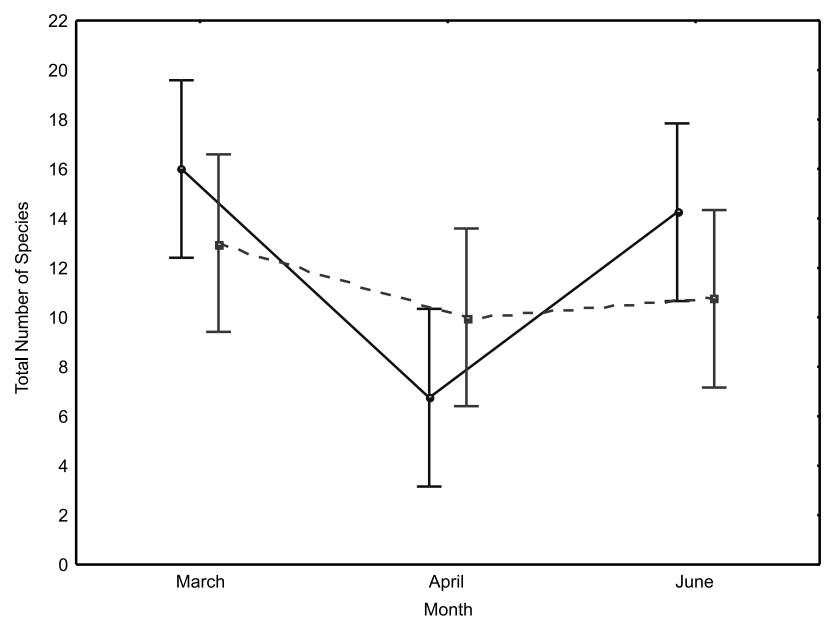

Figure 3 - Average (+/-Standard Deviation) of total number of species $/ 2300 \mathrm{~cm}^{3}$ for the three months. Control area: continuous line; impacted area: dashed line.

the total of polychaetes and the total of crustaceans (Table 1, Fig. 4 and 6).

Values for the total of bivalves were not significant among areas, months, or interaction of factors (Tab. 1, Fig. 5).

Values for the Shannon \& Wiener diversity index were not significant among areas, months, or interaction of factors (Fig. 7; Tab. 2). The Margalef's index of species richness showed no significant differences among neither areas nor interaction of factors A/M (area/month), but among months, with April showing the smallest value. (Fig. 8; Tab. 2).

MDS and ANOSIM using area as a factor showed no significant separation in groups of samples, revealing that community structure for the two areas remained the same (Fig. 9 and Tab. 3). MDS and ANOSIM using months as factor showed a separation in groups of

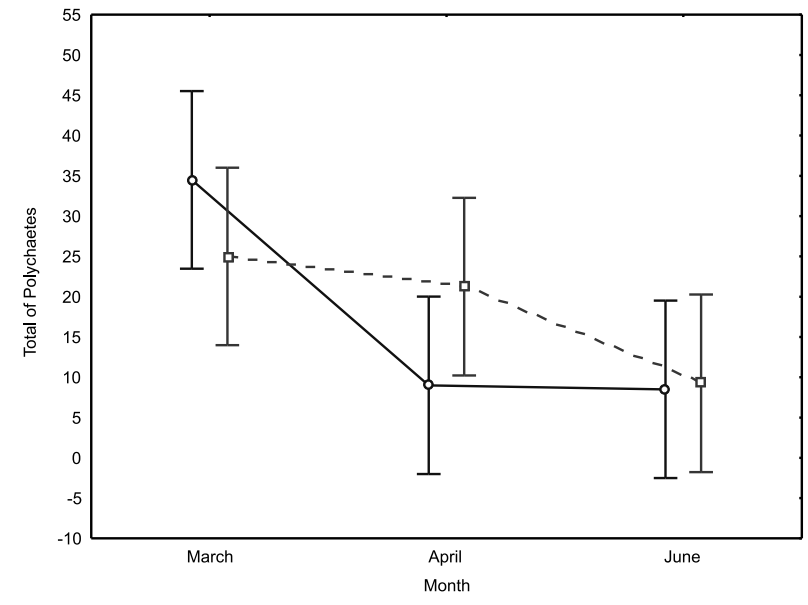

Figure 4 - Average (+/-Standard Deviation) of total of polychaetes for the three months. Control area: continuous line; impacted area: dashed line.

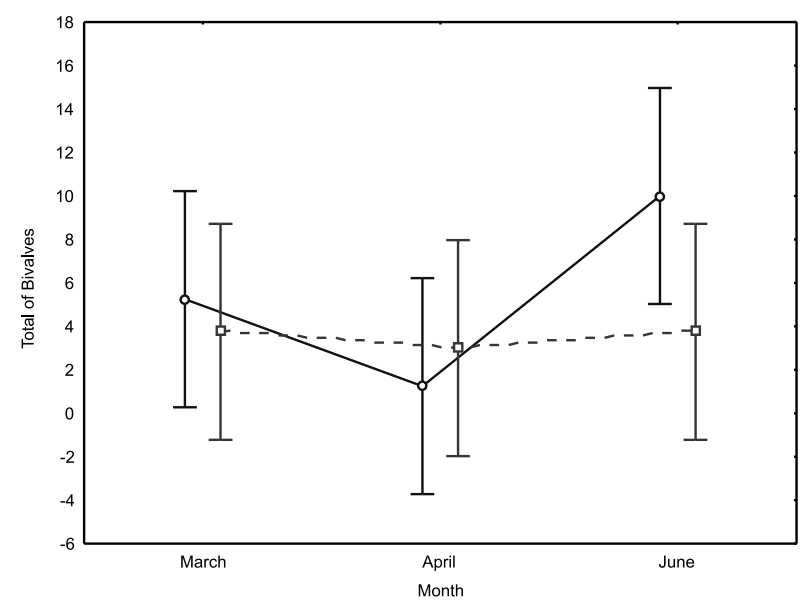

Figure 5 - Average (+/-Standard Deviation) of total of bivalves for the three months. Control area: continuous line; impacted area: dashed line.

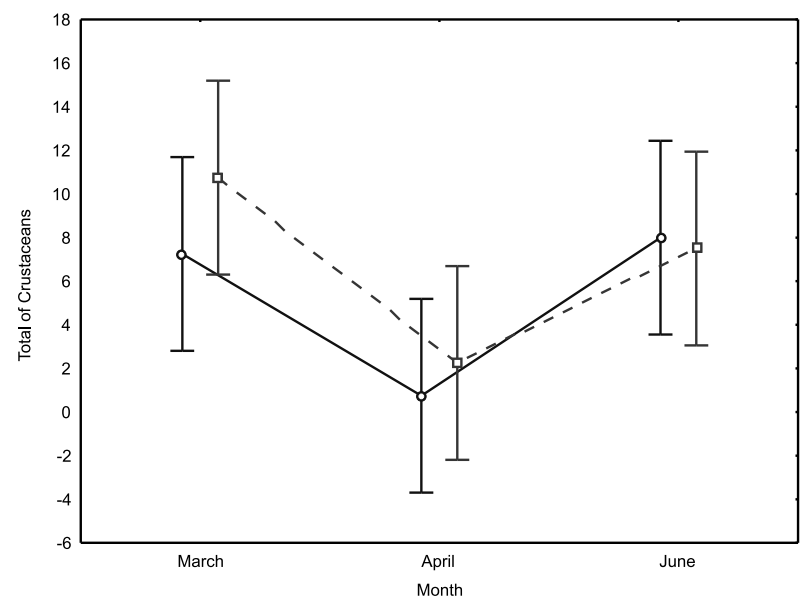

Figure 6 - Average (+/-Standard Deviation) of total of crustaceans for the three months. Control area: continuous line; impacted area: dashed line. 
Pelaes \& Borzone: Disturbance to macrobenthic communities by trawling.

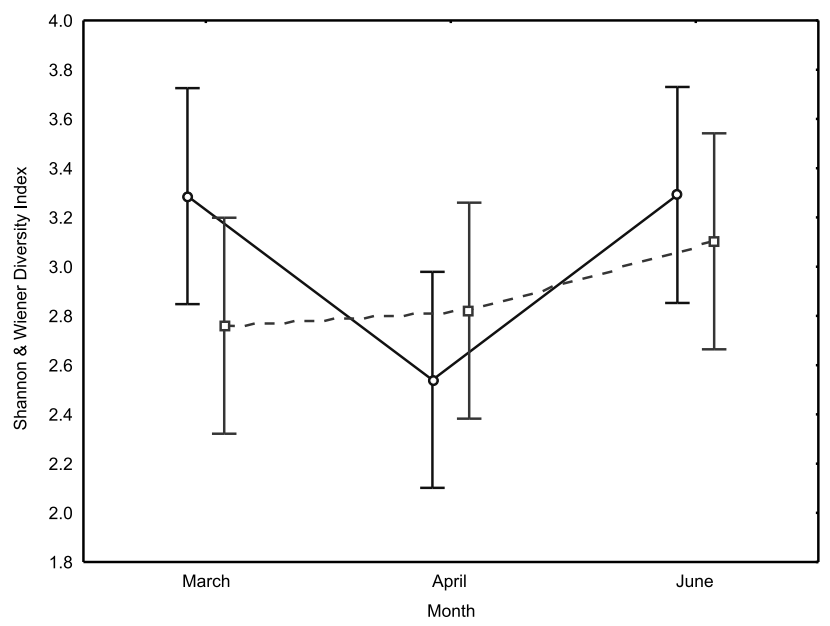

Figure 7 - Average (+/-Standard Deviation) of Shannon \& Wiener diversity index for the three months. Control area: continuous line; impacted area: dashed line.

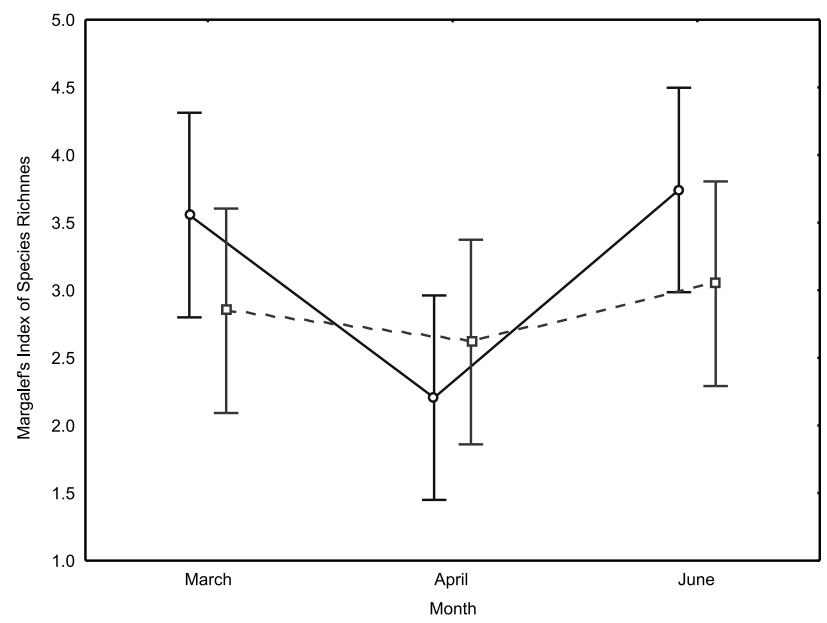

Figure 8 - Average (+/-Standard Deviation) of Margalef's index of species richness for the three months. Control area : continuous line; impacted area: dashed line.

samples for each month, revealing differences in the community structure throughout the sampling. (Fig. 10 and Tab. 3).

\section{DISCUSSION}

Three major groups of organisms formed the macrobenthos community at the study site: polychaetes, bivalves and crustaceans. Differences in the proportion of these groups were more related to temporal variation than to area variation. However, slight differences between areas may be related to trawling effects.

Hydrozoa were registered only in March for both areas. Although higher abundance of hydrozoa
Table 2 - Results of the MANOVA bifactorial for the Shannon \& Wiener diversity index and Margalef's index of species richness.

\begin{tabular}{ccccc}
\hline \hline & \multicolumn{2}{c}{ Shannon \& Wiener diversity } & \multicolumn{2}{c}{ Margalef's index of } \\
& index & & \multicolumn{2}{c}{ species richness } \\
& $\mathrm{F}$ & $\mathrm{p}$ & $\mathrm{F}$ & $\mathrm{p}$ \\
\hline Areas & 0.719 & 0.408 & 1.260 & 0.276 \\
Months & 3.166 & 0.066 & 4.194 & 0.032 \\
A/M & 1.886 & 0.180 & 1.590 & 0.231 \\
\hline \hline
\end{tabular}

fragments was found in the impacted area, it can easily be related to the passage through the mesh nets, once these organisms are located at the surface of the substratum and might be damaged by trawling itself. A similar pattern was found for the echinoid Lytechinus variegatus. Reproductive strategy of this echinoid might explain its occurrences in June (Junqueira et al, 1997) when higher number of recruits were reported in the control area, preserved from trawling perturbation.

Since bivalves are sedentary and remain within the sediment surface, they are also subject to trawling action. During the sample periods, bivalves were more abundant in the control area than at the impacted area in March and June, although no significant differences were found for this group. Crustaceans were more abundant in the impacted area, but they appeared in higher numbers mainly during the fishing period (March and June). Most crustaceans are vagile scavengers, and might be favored by the damage of other organisms by trawling. Ramsay et al. (1998) also found a larger amount of scavenger species in areas subjected to strong trawling in England. Higher densities of epifauna in lightly trawled areas and higher densities of predator and scavenger worms in heavily trawled areas were pointed out by EngeL \& Kvitek (1998) in central California on sand bottom at $180 \mathrm{~m}$ depth. According to these authors, motile invertebrates might be unaffected by trawl disturbance because they pass unharmed through the net mesh and perhaps benefit from organisms (food resource) that the net crushes or kills.

On the other hand, ecological descriptors did not show significant differences between the areas. However, variations among months might be related to the fishing closure period (April), when all descriptors showed the smallest values. This temporal variation was less evident in the impacted area. Vagile predators have great mobility and their densities might be rapidly homogenized, independently of the trawling exclusion in the narrow control area. The decrease of the macrobenthos descriptor values could be related to an increase in the number of vagile predators.

No trawling effect on benthos was detected by Kenchington et al (2001) in the Grand Banks of Newfoundland on a sandy bottom at 120-146 m depth. Pravoni et al (2000) observed that the number of taxa showed no immediate effects on sandy bottoms (24 m 


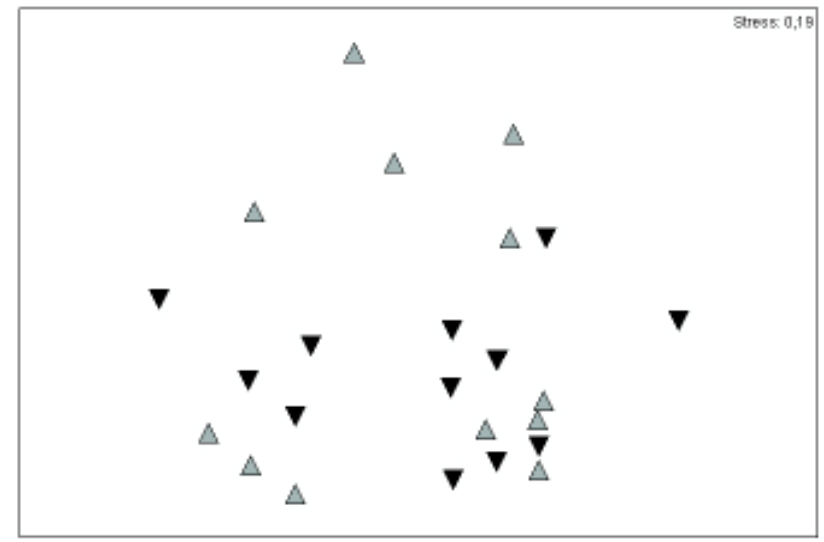

Figure 9 - General MDS for the total sample. There is no separation among the control (grey triangle) and impacted (black triangle) area.

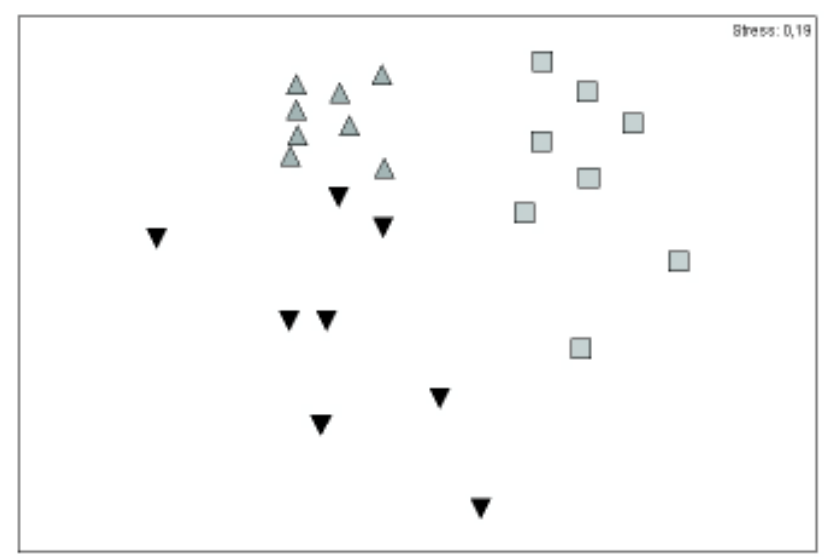

Figure 10 - General MDS made with all samples for all months of collection ( march = grey triangle; april = black triangle; june = square). It is noticed grouping of samples of each sampled month.

depth) in the Adriatic Sea, but increased in the trawled area after seven days.

Tuck et al (1998) report an increase in number of species, number of individuals and various diversity indexes in fished areas, as opposed to unfished controls.

Similar results were described by SparksMcConkey et al (2001), who did not find significant differences for richness or diversity indexes between trawled and control areas. However they verified that the number of individuals was different among areas as well as before and after trawling action.

According to Bemvenuti \& Rosa-Filho (1998), predators removal could favor the growth of prey populations, with a consequent increase in macrobenthonic density. Predation by fish and decapod crustaceans would maintain macrobenthos densities of soft bottoms below the environmental carrying capacity. Baptista et al. (2003) e Baptista-Metri et al. (2005), working in the Paraná coast, reports that crabs are one
Table 3 - ANOSIM values accomplished for areas and for all months.

\begin{tabular}{lcccc}
\hline \hline Group & $\mathrm{R}$ & $\begin{array}{c}\text { Significance } \\
\text { level (\%) }\end{array}$ & $\begin{array}{c}\text { Number of } \\
\text { Permutations }\end{array}$ \\
\hline Areas & & 0.177 & 4.2 & 999 \\
& & 0.749 & 0.1 & 999 \\
Months & $\mathrm{M} / \mathrm{A}$ & 0.615 & 0.4 & 999 \\
& $\mathrm{M} / \mathrm{J}$ & 0.896 & 0.2 & 999 \\
& $\mathrm{~A} / \mathrm{J}$ & 0.771 & 0.2 & 999 \\
\hline \hline
\end{tabular}

important component of the discard from shrimp trawling. Braga et al. (2001) found that most fish that dominate the shrimp icthyofauna by-catch belong to the Sciaenidae Family, whose members typically inhabit shallow coastal environments of sandy and/or muddy bottoms, and are important consumers of macroinvertebrates (DeLancey, 1989; McDermott, 1983).

The removal of top fish predators through intense fishing apparently released other predators such as crabs and starfish, thus changing benthic communities (Witman \& Sebens, 1992). Frid et al. (1999) also provide an example that links changes in the abundance of fish to changes in benthos: changes in fish biomass in the North Sea appear to have resulted in changes in the benthic taxonomic composition, along with an overall increase in predation pressure on benthos. However, such effects are difficult to identify without extensive study; tracking effects through marine foodwebs is difficult because of the inherently complex interactions and weak and indirect effects (Micheli, 1999).

The largest descriptor values found within the trawling months, and their subsequent decrease during the fishing closure period for both sampled sites, suggest that predation, and not trawling, might be controlling density and diversity of macrobenthos in this area.

Our results suggest that a direct effect of trawling perturbation was not observed in macrobenthic communities of the study area, in agreement with Gibbs et al (1980), who studied sandy bottom communities at $10 \mathrm{~m}$ in Botany Bay, Australia, and with Van Dolah et al (1991) studies at Port Royal (8 m) and St Helena (30 $\mathrm{m}$ ), also for sandy bottoms (apud Thrush \& Dayton, 2002).

However, our results could be biased by a small sample size or use of an ill-defined control area. Finally, we cannot ignore completely the possibility that up to some extent the observed results might be attributable to trawling effects.

\section{ACKNOWLEDGMENTS}

To all those that contributed in the sampling (Joaquim Netto Junior, Vader Braga e Daniel Rocha) and in identification of polychaeta (Heliatrice Hadlich). To Frederico Pereira Brandini for financing this project. 


\section{REFERENCES}

Baptista, C.; Pinheiro, M.A.A.; Blankensteyn, A. \& Borzone, C.A. 2003. Estrutura populacional de Callinectes ornatus Ordway, 1863 (Crustacea: Portunidae) no balneário Shangri-Lá (PR), Brasil. Rev. Bras. Zool., 20 (4): 661-666.

Baptista-Metri, C.; PINHEIRO, M.A.A.; Blankesteyn, A. \& Borzone, C.A. 2005. Biologia populacional e reprodutiva de Callinectes danae Smith (Crustácea, Portunidae), no Balneário Shangri-lá, Pontal do Paraná, Paraná. Brasil. Rev. Bras. Zool., 22 (2): 446453.

Bemvenuti, C. E. \& Rosa-Filho, J. 1998. Estrutura e dinâmica das associações de macroinvertebrados bentônicos dos ambientes estuarinos do Rio Grande do Sul: um estudo de caso. Avaliação e ações prioritárias para a conservação da biodiversidade da zona costeira e marinha. Rio Grande: FURG, Relatório técnico.

Blaber, S. J. M.; Cyrus, D.P.; Albaret, J. J.; Ching, C. V.; Day, J. W.; Elliott, M.; Fonseca, M. S.; Hoss, D .E.; Orensanz, J.; Potter, I. C. \& Silvert, W. 2000. Effects of fishing on the structure and functioning of estuarine and nearshore ecosystems. - ICES Journal of Marine Science, 57: p 590-602 .

Braga, M.S.C.; Salles, R de \& Fonteles-Filho, A. A. 2001. Ictiofauna acompanhante da pesca de camarões com rede de arrasto na zona costeira do município de Fortaleza, Estado do Ceará, Brasil. Arquivos de Ciências do Mar, Fortaleza, v. 34: p 4960.

Brandini, F. P. 2003. Recifes artificiais marinhos: uma proposta de conservação da biodiversidade e desenvolvimento da pesca artesanal através da criação de um "parque" marinho na costa do Estado do Paraná. PADCT III/CIAMB. Relatório técnico.

Delancey, L.B. 1989. Trophic relationship in the surf zone during the summer at folly beach, South $\mathrm{Ca}-$ rolina. Journal of Coastal Research, Charlottesville, Virginia, p. 477-488.

Engel, J. \& Kvitek, R. 1998. Effects of Otter Trawling on a Benthic Community in Monterey Bay National Marine Sanctuary. Conservation Biology. v. $12, n^{\circ} 6$, p. $1204-1214$.

Frid, C. L. J.; Hansson, S.; Ragnarsson, S. A.; Rijnsdorp, A.; Streigrimsson, S. A. 1999. Changing levels of predation on benthos as a result of exploitation of fish populations. Ambio. 28:578-82.

Junqueira, A.O.R., Ventura, C.R.R., De Carvalho, A.L.P.S, Schimdt, A.J. 1997. Population recovery of the sea urchin Lytechinus variegatus in a segrass flat (Araruama Lagoon, Brazil): the role of recruitment in disturbed environment. Invertebrate Reproduction and Development, Balaban, Philadelphia/Rehovot, v. 31 , n. $1 / 3$, p. 143-150.

Kaiser, M. J. 2003. Detecting the effects of fishing on seabed community diversity: importance of scale and sample size. Conservation Biology, v. 17, n. 2, p. 512-520.

Kenchington, E. L. R.; Prena, J.; Gilkinson, K. D.; Gordon, D. C.; Maclsaac, K., et al. 2001. Effects of experimental otter trawling on the macrofuna of a sand bottom ecosystem on the Grand Banks of Newfoundland. Can. J. Fish Aquat. Sci. 58: 104357.

McDermott, J.J. 1983. Food web in the surf zone of an exposed sandy beach along the mid-atlantic coast of the United States.. Department of Biology, Franklin and Marshall College, p. 529-537. Lancaster, Pennsylvania, USA

Micheli, F. 1999. Eutophication, fisheries and consumerresource dynamics in marine pelagic ecosystems. Science 285:325-26.

Noernberg, M. A. 2001. Processos morfodinâmicos no complexo estuarino de Paranaguá - Paraná - Brasil: um estudo a partir de dados in situ e landsattm. Curitiba. Tese (Doutorado em Geologia) - Setor de Ciências da Terra, Universidade Federal do Paraná.

Perez, J.A.A. \&. Pezzuto, P.R. 1998. Valuable shellfish species in the by-catch of shrimp fishery in southern Brazil: spatial and temporal patterns. Journal of Shellfish Reseach, 17(1); 303-309. Ckouthampton.

Pravoni, F.; Raicevich, S.; Franceschini, G.; Farrace, M. G. \& Giovanardi, O. 2000. Rapido trawling in the northern Adriatic Sea: effects on benthic communities in an experimental area. ICES J. Mar. Sci. 57:517-24.

Ramsay, K.; Kaiser, M. J. \& Hughes, R. N. 1998. Responses of benthic scavengers to fishing disturbance by towed gears in different habitats. UK: Journal of Experimental Marine Biology and Ecology. 224:73-89.

Sparks-McConkey, P.J. \& Watling, L. 2001. Effects on the ecological integrity of a soft-bottom habitat from a trawling disturbance. Hydrobiologia, Netherlands: Kluwer Academic Publishers, n. 456, p. 73-85.

Thrush, S. F. \& Dayton, P. K. 2002. Disturbance to marine benthic habitats by trawling and dredging: implication for marine biodiversity. Annu. Rev. Ecol. Syst, n. 33, p. 449-473.

Thrush, S. F.; Hewitt, J. E.; Funnell, G. A.; Cummings, V. J.; Ellis, J.; Schultz, D.; Talley, D. \& Norkko, A. 2001. Fishing disturbance and marine biodiversity: the role of habitat structure in simple soft-sediment systems. Marine Ecology Progress Series. v. 223, p. 277-286. 
Braz. J. Aquat. Sci. Technol., 2007, 11(2):45-51.

Tuck, I. D.; Hall, S. J.; Robertson, M. K.; Armstrong, E. \& Basford, D. J. 1998. Effects of physical trawling disturbance in a previously unfished sheltered Scottish sea loch. Mar. Ecol. Progr. Ser. 162:22742.

Veiga, F. A.; Angulo, R. J.; Marone, E.; Brandini F. P. 2004. Características sedimentológicas da plata- forma continental interna rasa na porção central do litoral paranaense. Boletim Paranaense de Geociências, Editora UFPR, n. 55, p. 67-75.

Witman, J. D.; Sebens, K. 1992. Regional variation in fish predation intensity: a historical perspective in the Gulf of Maine. Oecologia. 90:305-15. 